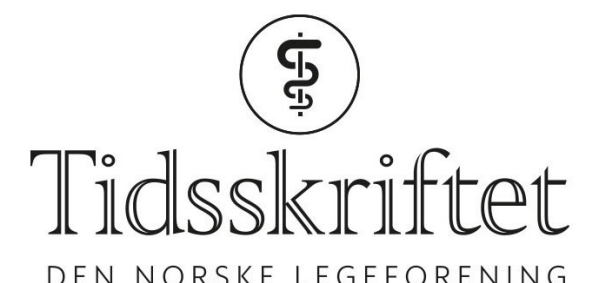

DEN NORSKE LEGEFORENING

\title{
Kortikosteroider mot Duchennes muskeldystrofi
}

FRA ANDRE TIDSSKRIFTER

ØYVIND STOPLE SIVERTSEN

Tidsskriftet

Behandling med kortikosteroider gir bedre gangfunksjon og bedre funksjon i arm og hånd hos pasienter med Duchennes muskeldystrofi.

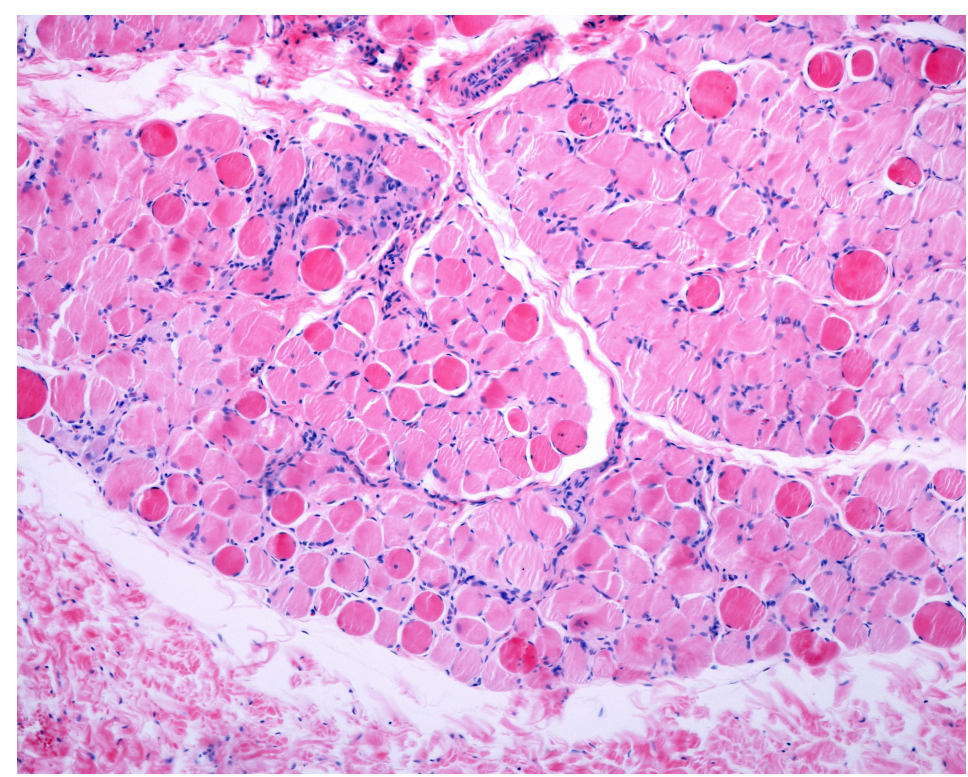

Muskeldystrofi er forårsaket av mutasjoner i dystrofin, det største kjente humane genet, lokalisert på kromosom Xq21. Illustrasjonsfoto: Science Photo Library/NTB scanpix

De siste årene er systemiske kortikosteroider i økende grad tatt i bruk i behandlingen av pasienter med Duchennes muskeldystrofi, og flere retrospektive studier har vist god effekt av slik behandling på gangfunksjonen. Nå viser en studie som nylig ble publisert i The Lancet også effekt på arm- og håndfunksjonen etter at pasienten ikke lenger kan gå (1).

Studien omfattet 440 pasienter med Duchennes muskeldystrofi i alderen 2-28 år. De ble fulgt i opptil ti år. Behandling med kortikosteroider utsatte tap av gangfunksjon med opptil 4,4 år og tap av funksjon i arm og hånd med opptil 8,o år sammenlignet med kortvarig eller ingen kortikosteroidbehandling.

- Dette er den første store, prospektive studien av effekten av kortikosteroider ved Duchennes muskeldystrofi gjennom hele livsløpet, sier Ellen Johanne Annexstad, som er barnelege og stipendiat ved Enhet for medfødte og arvelige nevromuskulære tilstander ved 
Oslo universitetssykehus.

- Den viser en overbevisende effekt av slik behandling, noe som vil kunne få betydning for klinisk praksis. Tatt i betraktning at Duchennes muskeldystrofi er en sjelden tilstand, er antallet studiedeltagere imponerende høyt. At også svenske gutter er inkludert, gir økt relevans for norske forhold, mener Annexstad, som likevel påpeker flere svakheter ved studien.

- Antallet voksne pasienter var lavt. Dessuten diskuterer ikke forfatterne det forhold at behandlingen ikke hadde effekt hos alle og at en del fikk så plagsomme eller alvorlige bivirkninger at de var nødt til å avslutte behandlingen. Det kunne vært interessant å vite sykdomsforløpet hos dem som avslutter behandling etter få år sammenlignet med forløpet hos dem som tolererer behandling inn i voksen alder, sier hun.

\section{LITTERATUR:}

1. CINRG Investigators. Long-term effects of glucocorticoids on function, quality of life, and survival in patients with Duchenne muscular dystrophy: a prospective cohort study. Lancet 2018;391: 451 - 61. [PubMed][CrossRef]

Publisert: 28. mai 2018. Tidsskr Nor Legeforen. DOI: 10.4045/tidsskr.18.0273

(C) Tidsskrift for Den norske legeforening 2020. Lastet ned fra tidsskriftet.no 